\title{
The Effect of PGPR Strains on Microbial Abundance in Maize Rhizosphere in Field Conditions
}

\author{
Nastasija Mrkovački · Ivica Đalović1 · Dragana Jošić² . \\ Dragana Bjelić · Milka Brdar Jokanović \\ ${ }^{1}$ Institute of Field and Vegetable Crops, Maksima Gorkog 30, 21000 Novi Sad, Serbia \\ ${ }^{2}$ Institute of Soil Science, Genetic Laboratory, T. Drajzera 7, 11000 Belgrade, Serbia
}

\begin{abstract}
Summary: Plant growth promoting rhizobacteria (PGPR) represent a wide variety of bacteria inhabiting the root surface and root vicinity. They are directly or indirectly involved in promoting plant growth and development via production and secretion of various regulatory compounds in the rhizosphere. PGPR are generally beneficial to a wide range of crops including maize. The main objective of this study was to determine the effect of PGPR strains on the microbial abundance in maize rhizosphere. The trial was conducted at Rimski Šančevi experimental field of Institute of Field and Vegetable Crops in Novi Sad, Serbia. The trial included five maize hybrids (NS 3014, NS 4015, NS 5043, NS 6010 and NS 6030) developed at the Institute and three treatments with microorganisms. Non-inoculated treatment was control. Inoculation was performed with Bacillus Q7, Psendomonas PS2 and their mixture with Azotobacter chroococcum (Q7 + PS2 + AC). Application method was incorporation immediately before planting with liquid culture of strains (density $10^{\circ} \mathrm{CFU} / \mathrm{ml}$ ). It was observed that the certain treatment with rhizobacteria increased the number of all three studied microbial groups in the rhizosphere of the same hybrid. The best effect on the number of microorganisms in the rhizosphere of NS 6010 was achieved with Q7 + PS2 + AC, in NS 5043 with Q7 and with PS2 in NS 4015. The results obtained in this study indicate the importance of PGPR in crop production, which requires a constant expansion of knowledge about the mutual interactions of plants and microorganisms.

Keywords: Azotobacter, Bacillus, inoculation, maize, Pseudomonas, PGPR, rhizosphere, strains
\end{abstract}

\section{Introduction}

Maize is one of the most important cereal crops in the world. In 2010, this crop was grown in an area of nearly 162 million ha and occupied second place in overall production (http://faostat.fao.org). In Serbia, maize is grown on about $1,200,000$ ha and the total grain production ranges between 4 and 7 million tons per year. The grain yield of maize depends on the genetic potential of a hybrid, soil characteristics, agrotechnical measures and climatic factors (Jocković et al. 2010, Đalović 2014). One of the major causes of reoccurring yield reduction is depletion of field nutrients combined with detrimental effects of poor land fertility (Adjanohoun et al. 2011).

Recently, plant growth promoting rhizobacteria (PGPR) have been used to enhance crop yield and improve agriculture sustainability (Vessey 2003). PGPR represent a wide variety of bacteria inhabiting the root

Corresponding author:

nastasija.mrkovacki@ifvcns.ns.ac.rs

Acknowledgements:

This study was conducted as a part of the project TR 31073 "Improvement of maize and sorghum production under stress conditions", funded by the Ministry of Education, Science and Technological Development of the Republic of Serbia. surface and its vicinity. They are directly or indirectly involved in promoting plant growth and development via production and secretion of various regulatory chemicals in the rhizosphere. PGPR are directly involved in increased uptake of nitrogen, synthesis of phytohormones, solubilization of minerals such as phosphorus, and production of siderophores that chelate iron and make it available to the plant root (Bowen \& Rovira 1999) and therefore are used as inoculants for biofertilization, phytostimulation and biocontrol (Bloemberg \& Lugtenberg 2001). Establishment of a significant number of PGPRs in rhizosphere and plant tissues by inoculation leads to increased biomass (even grain production) in later developmental stages (Bashan et al. 2004).

Studies of Bashan (1998), Gupta et al. (2000), and Lucy et al. (2004) have also shown that the growthpromoting ability of some bacteria may be highly specific to certain plant species, cultivars and genotypes. Many authors have pointed out the possibility of selecting PGPR strains on plant genotype level in order to select the most effective strains for each maize hybrid (Hajnal et al. 2001, Sharifi et al. 2011). Picard et al. (2008) observed that PGPR were earlier stimulated in the rhizosphere of hybrid maize than in its two parental lines and that each maize genotype stimulated the AMF (arbuscular mycorrhizal fungi) population differently. 
In our previous studies we pointed out the importance of the application of PGPR microorganisms on microbiological activity in maize rhizosphere (Mrkovački \& Bjelić 2011, Mrkovački et al. 2012). The main objective of this study was to determine the effect of PGPR on the microbial abundance in maize rhizosphere and select the most effective strains compatible with particular maize hybrid.

\section{Material and Methods}

The trial was conducted at the Rimski Šančevi Experiment Field of Institute of Field and Vegetable Crops in Novi Sad, Serbia. The field is located on a calcareous chernozem on loess terrace. A complete randomized blocks (split-plot) design with four replications was used in this study consisting of five commercial high-yielding maize hybrids and three treatments with microorganisms. The hybrids (NS 3014, NS 4015, NS 5043, NS 6010 and NS 6030) originating from the Institute of Field and Vegetable Crops belong to five FAO maturity groups, with NS 3014 and NS 6030 representing the earliest and the latest, respectively. Maize was sown on standard sowing date (10 th April) with the spacing $75 \times 22 \mathrm{~cm}$. The soil was fertilized with $250 \mathrm{~kg} \mathrm{NPK} \mathrm{ha-1}$ in autumn and $140 \mathrm{~kg} \mathrm{ha}^{-1}$ urea in spring.

Inoculation was performed with Bacillus Q7, Pseudomonas PS2, and their mixture with well known Azotobacter chroococcum biofertilizer strain (Q7 + PS2 + AC). Strains of Bacillus Q7 and Pseudomonas PS2 were isolated from maize rhizosphere, while strain of Azotobacter chroococcum was isolated from rhizosphere of sugarbeet. Azotobacter chroococcum was cultured for $72 \mathrm{~h}$ in Burk's N-free broth, and Bacillus and Pseudomonas were cultured for $48 \mathrm{~h}$ in nutrient broth. Bacteria were grown at optimal temperature of $28^{\circ} \mathrm{C}$, at a shaking rate of 150 rpm (on Edmund Bühler Shaker SM-30 B). Application method was incorporation immediately before planting with liquid culture of strains (density $10^{9} \mathrm{CFU} \mathrm{ml-1}$ ). Non-inoculated treatment was control.
The rhizosphere soil for microbiological analysis was sampled at two sampling periods (June and September 2012), at six-leaf and twelve-leaf stage of maize. Total number of microorganisms was determined in soil agar (dilution $10^{7}$ ), and the number of free-living nitrogenfixing bacteria and Azotobacter in Fiodorov medium (dilutions $10^{6}$ and $10^{2}$ ) (Jarak \& Đurić 2004). All microbiological analyses were performed in three replications and the average number of microorganisms was calculated at $1.0 \mathrm{~g}$ absolutely dry soil. ANOVA statistical method was used to determine lowest significant differences for average values and confidence interval of 95\% (LSD 0.05\%) (Stanković et al. 2002).

\section{Results and Discussion}

The number of microorganisms is one of the principal parameters of soil biogeny. This number was significantly increased by inoculation and the increase depended on the treatment with PGPR, maize hybrids, and period of sampling (Table 1).

On average for all hybrids, total number of microorganisms was significantly higher after inoculation with Q7 $\left(228.38 \times 10^{7} \mathrm{~g}^{-1}\right)$ and PS2 $(208.48$ $\left.\times 10^{7} \mathrm{~g}^{-1}\right)$ compared to the control $\left(171.82 \times 10^{7} \mathrm{~g}^{-1}\right)$. On average for all treatments, a significantly higher microbial total number compared to NS 6030 and NS 3014 was recorded in the rhizosphere of NS 6010, NS 5043 and NS 4015. A significant increase after inoculation with Q7 was observed in the rhizosphere of NS 6010 and NS 5043 (202.52 and $\left.393.57 \times 10^{7} \mathrm{~g}^{-1}\right)$. Significantly higher total number of microorganisms in rhizosphere of NS $6030\left(190.47 \times 10^{7} \mathrm{~g}^{-1}\right)$, NS 6010 $\left(259.41 \times 10^{7} \mathrm{~g}^{-1}\right)$ and NS $4015\left(302.59 \times 10^{7} \mathrm{~g}^{-1}\right)$ was recorded with PS2, while the best effect on this number in the rhizosphere of NS 6010 was obtained with Q7 + PS2 + AC $\left(310.49 \times 10^{7} \mathrm{~g}^{-1}\right)$. The total number of microorganisms on average was significantly higher at the first sampling period $\left(302.93 \times 10^{7} \mathrm{~g}^{-1}\right)$ compared to the second period $\left(121.53 \times 10^{7} \mathrm{~g}^{-1}\right)$. Significant effect of the sampling periods was observed in all treatments (Table 1).

Table 1. Total number of microorganisms in rhizosphere of different maize hybrids depending on inoculation and sampling period $\left(\times 10^{7} \mathrm{~g}^{-1}\right.$ absolutely dry soil $)$

\begin{tabular}{lcccccccc}
\hline \multirow{2}{*}{ Treatment (T) } & \multicolumn{9}{c}{ Hybrids (H) } & \multicolumn{3}{c}{ Sampling (S) } \\
\cline { 2 - 9 } & NS 3014 & NS 4015 & NS 5043 & NS 6010 & NS 6030 & Average & I & II \\
\hline Control & 200.70 & 161.36 & 210.85 & 136.82 & 149.36 & 171.82 & 263.00 & 80.60 \\
Q7 & 195.74 & 180.77 & 393.57 & 202.52 & 169.30 & 228.38 & 348.10 & 108.60 \\
PS2 & 173.43 & 302.59 & 116.51 & 259.41 & 190.47 & 208.48 & 290.80 & 126.10 \\
Q7 + PS2 + AC & 178.36 & 196.21 & 153.34 & 310.49 & 161.13 & 199.91 & 269.90 & 129.90 \\
Average & 182.51 & 226.52 & 221.14 & 257.47 & 173.63 & 212.26 & 302.93 & 121.53 \\
\hline & LSD & $\mathrm{S}$ & $\mathrm{T}$ & $\mathrm{H}$ & $\mathrm{S} \times \mathrm{T}$ & $\mathrm{S} \times \mathrm{H}$ & $\mathrm{T} \times \mathrm{H}$ & $\mathrm{S} \times \mathrm{T} \times \mathrm{H}$ \\
\end{tabular}


Similarly, Jarak et al. (2011) showed that application of Azotobacter chroococcum resulted in higher grain yield in all analysed hybrids (Tisa, NS 444, NS 5010), and also led to increase of the total number of microorganisms and Azotobacter in the rhizosphere. On average for all hybrids, the number of Azotobacter was reduced in all treatments, compared to control $\left(109.61 \times 10^{2} \mathrm{~g}^{-1}\right)$ (Table 2). A significant reduction was recorded with PS2 $\left(86.46 \times 10^{2} \mathrm{~g}^{-1}\right)$. The highest number, on average for all treatments, was obtained in the rhizosphere of NS 6030 $\left(113.52 \times 10^{2} \mathrm{~g}^{-1}\right)$. A significantly higher number was recorded in the rhizosphere of NS 6030 and NS 3014 compared to others. When we look at treatments, the largest number in the rhizosphere of NS 5043 and NS 3014 was obtained with Q7. Inoculation with PS2 increased the number of azotobacters compared to the control only in NS 5043 rhizosphere, while in the rhizosphere of NS 4015 the number was reduced in all treatments. The best effect on the number of Azotobacter in the rhizosphere of NS 6030 and NS 6010 was achieved with Q7 + PS2 + AC (136.44 and $109.56 \times$ $\left.10^{2}\right)$. Number of Azotobacter on average for all hybrids was higher at the first sampling period $\left(99.47 \times 10^{2} \mathrm{~g}^{-1}\right)$ than the second $\left(85.13 \times 10^{2} \mathrm{~g}^{-1}\right)($ Table 2$)$.
Similar results were obtained by Cvijanović et al. (2007) who found an increase of microbial number and maize yield in response to Azotobacter chroococcum, Azotobacter vinelandii, Azospirillum lipoferum, Bacillus megatherium, Bacillus subtilis and Klebsiella planticola application. Some previous studies suggested that the presence of microorganisms in the maize rhizosphere varied and that total number of microorganisms and number of Azotobacter increased in the course of the growing season (Govedarica et al. 1999, Bjelić et al. 2010).

On average for all hybrids, the number of freeliving nitrogen-fixing bacteria significantly increased by inoculation in all treatments, while the best effect on average for all treatments was achieved in the rhizosphere of NS $6010\left(224.49 \times 10^{6} \mathrm{~g}^{-1}\right)$ (Table 3). Inoculation with Q7 significantly increased the number of free-living nitrogen-fixing bacteria in NS 6030, 5043 and 3014 rhizosphere compared to the control. Application of PS2 led to a significant increase in the rhizosphere of 4015 and also had a positive effect on the number in the rhizosphere 6030, 6010 and 5043, while Q7 + PS2 + AC had significant effect in the rhizosphere of NS 6030, 6010 and 3014.

Table 2. Number of Azotobacter in rhizosphere of different maize hybrids depending on inoculation and sampling period $\left(\times 10^{2} \mathrm{~g}^{-1}\right.$ absolutely dry soil)

\begin{tabular}{lcccccccc}
\hline \multirow{2}{*}{ Treatment (T) } & \multicolumn{9}{c}{ Hybrids (H) } & \multicolumn{3}{c}{ Sampling (S) } \\
\cline { 2 - 9 } & NS 3014 & NS 4015 & NS 5043 & NS 6010 & NS 6030 & Average & I & II \\
\hline Control & 102.92 & 126.73 & 111.63 & 90.61 & 116.15 & 109.61 & 113.3 & 105.9 \\
Q7 & 130.57 & 18.19 & 120.58 & 89.23 & 106.16 & 92.95 & 101.3 & 60.1 \\
PS2 & 74.42 & 103.55 & 113.16 & 43.20 & 97.97 & 86.46 & 112.8 & 84.6 \\
Q7 + PS2 + AC & 122.99 & 83.21 & 35.19 & 109.56 & 136.44 & 97.48 & 84.3 & 110.7 \\
Average & 109.33 & 68.32 & 89.64 & 80.66 & 113.52 & 92.30 & 99.47 & 85.13 \\
\hline & LSD & S & T & H & S $\times \mathrm{T}$ & $\mathrm{S} \times \mathrm{H}$ & $\mathrm{T} \times \mathrm{H}$ & $\mathrm{S} \times \mathrm{T} \times \mathrm{H}$ \\
\hline
\end{tabular}

Table 3. Number of free-living nitrogen-fixing bacteria in rhizosphere of different maize hybrids depending on inoculation and sampling period $\left(\times 10^{6} \mathrm{~g}^{-1}\right.$ absolutely dry soil $)$

\begin{tabular}{lcccccccc}
\hline \multirow{2}{*}{ Treatment (T) } & \multicolumn{9}{c}{ Hybrids (H) } & \multicolumn{3}{c}{ Sampling (S) } \\
\cline { 2 - 9 } Control & NS 3014 & NS 4015 & NS 5043 & NS 6010 & NS 6030 & Average & I & II \\
Q7 & 140.87 & 153.60 & 195.52 & 156.86 & 72.52 & 143.88 & 199.00 & 88.80 \\
PS2 & 216.34 & 87.63 & 264.72 & 165.32 & 182.52 & 183.30 & 306.30 & 72.50 \\
Q7 + PS2 + AC & 124.39 & 241.67 & 203.14 & 240.58 & 137.17 & 189.39 & 287.80 & 76.50 \\
Average & 265.08 & 159.67 & 107.97 & 267.56 & 147.32 & 189.52 & 295.70 & 83.30 \\
\hline & 201.94 & 162.99 & 191.94 & 224.49 & 155.67 & 187.40 & 296.60 & 77.43 \\
\hline & LSD & $\mathrm{S}$ & $\mathrm{T}$ & $\mathrm{H}$ & $\mathrm{S} \times \mathrm{T}$ & $\mathrm{S} \times \mathrm{H}$ & $\mathrm{T} \times \mathrm{H}$ & $\mathrm{S} \times \mathrm{T} \times \mathrm{H}$ \\
\end{tabular}


The number of free-living nitrogen-fixing bacteria on average for all hybrids was significantly higher in the first period $\left(296.6 \times 10^{6} \mathrm{~g}^{-1}\right)$ than in the second $(77.43$ $\left.\times 10^{6} \mathrm{~g}^{-1}\right)$. Observed by the sampling period, significant effect was recorded in all the treatments, as determined for the total number of microorganisms (Table 3).

Co-inoculation (Azotobacter, Bacillus, Pseudomonas) had an advantage compared to single inoculation, which is similar in our results, while in case of single strains, better effects were achieved in Pseudomonas and Azotobacter treatments. Inoculation increased the number of Azotobacter (103.25\%), pseudomonads $(82.29 \%)$ and aerobic spore-forming bacteria $(52.65 \%)$ as well as height $(17.15 \%)$ and dry weight $(35.48 \%)$ of maize plants (Jarak et al. 2012). Hajnal-Jafari (2010) studied the effect of co-inoculation of NS 640 maize hybrid on the grain yield and microbiological activity in the rhizosphere. The results obtained over the period of three years showed that the average grain yield increased when microbial inoculants were used, and that microbiological variants had a significant effect on the total number of microorganisms, number of aminoheterotrophs, free-living nitrogen-fixing bacteria and phosphorus-mobilizing bacteria. Mixture of biofertilizers, biostimulants and biopesticides ( $A$. chroococcum, A. vinelandi, A. lipoferum, B. megaterium, and $B$. subtilis) caused an increase in the yield of all three investigated maize hybrids (NSSC-640, Balkan, NSSC666), as reported by Govedarica et al. (2002). Results of Hamidi et al. (2009) revealed that co-inoculation with PGPR (A. chroococcum, A. lipoferum, A. brasilense, and $P$. fluorescens) had the highest promoting effect on grain yield of maize hybrids. The best results on dry matter accumulation and yield of maize hybrids were obtained for the plots in which seeds were inoculated with Azotobacter bacteria compared with Azosprilium and Azotobacter + Azosprilium priming (Sharifi et al. 2011).

\section{Conclusions}

The results showed that effect of inoculation varied depending on the PGPR treatment and the type of hybrid. Concerning the effect of inoculation on hybrids, the largest total number of microorganisms and free $\mathrm{N}$-fixing bacteria was found in the rhizosphere of NS 6010, while significantly smaller number of these groups was found in the rhizosphere of NS 6030, where we obtained the highest number of Azotobacter.

Certain treatment with rhizobacteria increased the number of all three studied microbial groups in the rhizosphere of the same hybrid. The best effect on the number of microorganisms in the rhizosphere of NS 6010 was achieved with Q7 + PS2 + AC, in NS 5043 with Q7 and with PS2 in NS 4015. On average, number of studied microbes was higher at the first sampling period than in the second. The results obtained in this study indicate the importance of PGPR in crop production, which requires a constant expansion of knowledge about the mutual interactions of plants and microorganisms.

\section{References}

Adjanohoun, A., Allagbe, M., Noumavo, P. A., Gotoechan-Hodonou, H., Sikirou, R., Dossa, K. K., GleleKakaï, R., Kotchoni, S. O., \& Baba-Moussa L. (2011). Effects of plant growth promoting rhizobacteria on field grown maize. Journal of Animal \& Plant Sciences, 11(3): 1457-1465.

Bashan, Y. (1998). Inoculants for plant growth-promoting bacteria in agriculture. Biotechnol. Adv 16: 729-770.

Bashan, Y., Holguin, G., \& De-Bashan, L. E. (2004). Azospirillumplant relationships: physiological, molecular, agricultural and environmental advances. Can. J. Microbiol. 50(8): 521-577.

Bjelić, D., Mrkovački, N., Jarak, M., Jošić, D., \& Đalović, I. (2010). Effect of PGPR on the early growth of maize and microbial abundance in rhizosphere. Contemp. Agric. 59(3-4): 339-345.

Bloemberg, G. V., \& Lugtenberg, B. J. J. (2001). Molecular basis of plant growth promotion and biocontrol by rhizobacteria. Curr. Opin. Plant Biol. 4: 343-350.

Bowen, G. D., \& Rovira, A. D. (1999). The rhizosphere and its management to improve plant growth. Adv. Agron. 66: 1-102.

Cvijanović, G., Milošević, N., \& Jarak, M. (2007). The importance of diazotrophs as biofertilisers in the maize and soybean production. Genetike, 39(3): 395-404.

Đalović, I. (2014). More important morphological traits and the content of mineral elements in maize at the different levels of fertilization (In Serbian). Doctoral dissertation. University of Novi Sad, Faculty of Agriculture.

Govedarica, M., Jeličić, Z., Jarak, M., Milošević, N., Stojnić, N., Rašković, D., \& Pavlović, M. (1999). Effect of diazotrophs and P -mobilisers on microbial activity under maize. Proc. Res. Pap. PKB-INI Agroekonomik, 5(1): 115-121.

Govedarica, M., Milošević, N., Jarak, M., Đurić, S., Jeličić, Z., Kuzevski, J., \& Đorđević, S. (2002). Application of biofertilizers, biostimulators and biopesticides in agricultural production (In Serbian). Zbornik radova Naucnog instituta za ratarstvo i pourtarstvo, 37: 85-95.

Gupta, A., Gopal, M., \& Tilak, K. V. (2000). Mechanism of plant growth promotion by rhizobacteria. Indian J. Exp. Biol. 38: 856862.

Hajnal, T., Govedarica, M., \& Jeličić, Z. (2001). Uticaj bakterizacije na brojnost mikroorganizama i sadržaj azota u zemljištu pod usevom kukuruza. Acta Agriculturae Serbica, 6(11): 77-90.

Hajnal-Jafari, T. (2010). The effect of inoculation on the maize yield and microbial activity in the soil (In Serbian). Doctoral dissertation. University of Novi Sad, Faculty of Agriculture.

Hamidi, A., Chaokan, R., Asgharzadeh, A., Dehghaoshoar, M., Ghalavand, A., \& Malakouti, M. J. (2009). Effect of plant growth promoting rhizobacteria (PGPR) on phenology of late maturity maize (Zea mays L.) hybrids. Iranian Journal of Crop Sciences, 11(3): 249-270.

Jarak, M., \& Đurić, S. (2004). Laboratory Manual of Microbiology (In Serbian). University of Novi Sad, Faculty of Agriculture.

Jarak, M., Jeličić, Z., Kuzevski, J., Mrkovački, N., \& Đurić, S. (2011). Application of Azotobacter in maize production - the effect on microbial activity in soil and grain yield (In Serbian). Contemporary Agriculture, 60(1-2): 80-85.

Jarak, M., Mrkovački, N., Bjelić, D., Jošić, D., Hajnal-Jafari, T., \& Stamenov, D. (2012). Effects of plant growth promoting rhizobacteria on maize in greenhouse and field trial. African Journal of Microbiology Research, 6(27): 5683-5690.

Jocković, Đ., Stojaković, M., Ivanović, M., Bekavac, G., Popov, R., \& Đalović I. (2010). NS maize hybrids - today and tomorrow. Ratar. Povrt. 47(1): 325-333. 
Lucy, M., Reed, E., \& Glick, B. R. (2004). Application of free living plant growth promoting rhizobacteria. Antonie van Leeuwenboek Int. J. Gen. And Mol. Microbiol. 86: 1-25.

Mrkovački, N., \& Bjelić, D. (2011). Plant growth promoting rhizobacteria (PGPR) and their effect on maize (In Serbian). Ratar. Povrt. 48(2): 305-312. doi: 10.5937/ratpov1102305M

Mrkovački, N., Jarak, M., Đalović, I., \& Jocković, Đ. (2012). The importance and effect of apllying PGPR on the microbial activity in maize rhizosphere (In Serbian). Ratar. Povrt. 49 (3): 335-344. doi:10.5937/ratpov49-1915
Picard, C., Baruffa, E., \& Bosco, M. (2008). Enrichment and diversity of plant-probiotic microorganisms in the rhizosphere of hybrid maize during four growth cycles. Soil Biol. Biochem. 40: 106-115.

Sharifi, R. S., Khavazi, K., \& Gholipouri, A. (2011). Effect of seed priming with plant growth promoting Rhizobacteria (PGPR) on dry matter accumulation and yield of maize (Zea mays L.) hybrids. Food, Arriculture and Environment, 9(3-4): 393-397.

Stanković, J., Ralević, N., \& Ralević-Ljubanović, I. (2002). Statistics with applications in agriculture. Mladost biro, Beograd, 218-229.

Vessey, J. K. (2003). Plant growth-promoting rhizobacteria as biofertilizers. Plant Soil 255: 571-586.

\section{Efekat PGPR sojeva na brojnost mikroorganizama u rizosferi kukuruza u poljskim uslovima}

\section{Nastasija Mrkovački · Ivica Đalović · Dragana Jošić . Dragana Bjelić · Milka Brdar Jokanović}

Sažetak: Rizobakterije koje poboljšavaju rast biljaka (PGPR) predstavljaju širok spektar bakterija koje naseljavaju prostor oko/na površini korena. Direktno ili indirektno su uključene u ubrzanje rasta i razvoja biljaka putem proizvodnje i lučenja različitih regulatornih materija u rizosferu. PGPR su generalno korisne kod širokog spektra useva uključujući kukuruz. Osnovni cilj ovog istraživanja bio je ispitivanje efekta PGPR sojeva na zastupljenost mikroorganizama u rizosferi. Ogled je postavljen na eksperimentalnoj parceli Rimski šančevi Instituta za ratarstvo i povrtarstvo u Novom Sadu i uključivao je pet hibrida kukuruza poreklom iz Instituta (NS 3014, NS 4015, NS 5043, NS 6010 i NS 6030); kontrolu (bez inokulacije) i tri tretmana bakterijama koje poboljšavaju rast biljaka. Inokulacija je izvršena sa Pseudomonas PS2, Bacillus Q7 i njihovom mešavinom sa Azotobacter chroococcum (Q7 + PS2 + AC). Sojevi su primenjeni inkorporacijom tečne kulture (gustine $10^{9} \mathrm{CFU} / \mathrm{ml}$ ) neposredno pre setve. Rezultati su pokazali da kod određenog hibrida određeni tretman rizobakterijama povoljno utiče na brojnost kod sve tri analizirane grupe mikroorganizama. Najpovoljniji efekat na broj mikroorganizama u rizosferi hibrida NS 6010 postignut je primenom tretmana Q7 + PS2 + AC, kod NS 5043 primenom Q7, a kod NS 4015 primenom PS2.

Ključne reči: Azotobacter, Bacillus, inokulacija, kukuruz, Psendomonas, PGPR, rizosfera, sojevi 